\title{
Some biological traits of the parasitoid wasp Rhopalicus tutela (Hymenoptera: Pteromalidae) in spruce forests of Moscow Region, Russia
}

\section{Ekaterina Chilakhsaeva}

All-Russian Research Institute of Silviculture and Mechanization of Forestry, Institutskaya ul., 5, Pushkino, Moscow Region, 141202, Russian Federation

Address correspondence and requests for materials to Ekaterina Chilakhsaeva, kchilahsaeva@yandex.ru

\begin{abstract}
Some biological traits of Rhopalicus tutela (Walker), a parasitoid of the European spruce bark beetle Ips typographus (L.), were studied both in forests of Moscow Region, Russia, and under laboratory conditions. Females of $R$. tutela have mature eggs after overwintering and thus do not need additional feeding to lay eggs. Under laboratory conditions at $8^{\circ} \mathrm{C}$, the life expectancy of males is $58 \pm 44$ days and that of females is $36 \pm 45$ days. An increase of temperature shortens the developmental period of $R$. tutela, which can proceed without diapause. The duration of one generation in the laboratory at $22-24{ }^{\circ} \mathrm{C}$ is 14-16 days. In spruce forests of Moscow Region, $R$. tutela has two or three generations per year.
\end{abstract}

Keywords: Rhopalicus tutela, Ips typographus, parasitoid, biological trait, laboratory insect culture, biological protection, spruce forest

\section{Introduction}

Rhopalicus tutela is a polyphagous ectoparasitoid of many genera and species of bark beetles (Curculionidae: Mesoptiliinae, Molytinae, Scolytinae) (Noyes, 2019) and also of Mikiola fagi (Hartig) (Diptera: Cecidomyiidae) (Tselikh, 2012). Biological traits of $R$. tutela were previously studied by many domestic and foreign researchers (Bouček, Půlpán and Śedivý, 1953; Hedqvist, 1963; Kharitonova, 1972; Girits, 1975; Kolomiets and Bogdanova, 1980; Eck, 1990; Krüger and Mills, 1990; Hougardy and Gregoire, 2003, 2004). This parasitoid can be successfully bred under laboratory conditions and thus potentially used as a prospective agent for biological protection of spruce forests against Ips typographus (L.) (Coleoptera: Curculionidae: Scolytinae). The first experiments on cultivation of R. tutela under laboratory conditions on spruce logs showed positive results (Chilakhsaeva, 2017). Nevertheless, to develop methods of mass reproduction of the parasitoid, a better and more complete knowledge of the basic biological characteristics of this species is needed. The present study was aimed at studying phenology, as well as fertility and life expectancy of parasitoids in the laboratory.

\section{Materials and methods}

Copyright: (c) 2020 Chilakhsaeva. This is an open-access article distributed under the terms of the License Agreement with Saint Petersburg State University, which permits to the authors unrestricted distribution, and self-archiving free of charge.

Funding: No funding information provided.

Observations were made on standing and windfall trees of middle age which were infested with I. typographus. Work was carried out in the spruce woods with old local outbreaks of I. typographus in the Pushkino District of Moscow Region and in the laboratory of the All-Russian Research Institute of Silviculture and Mechanization of Forestry (ARRISMF). A total of 256 adults of R. tutela were collected and studied during 2013-2016 and in 2019. 


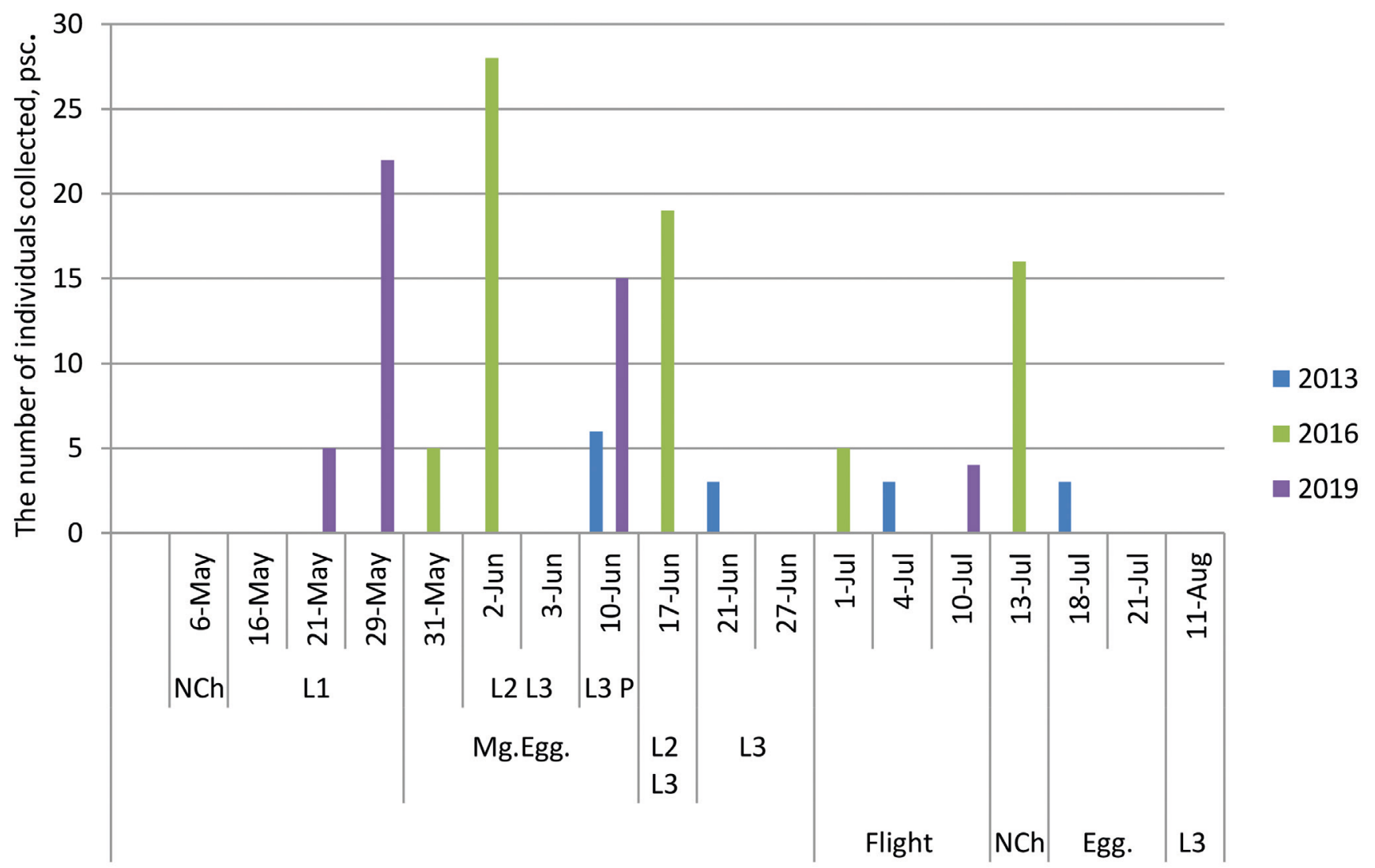

Fig. 1. The occurrence of Rhopalicus tutela in the forest on trees populated by Ips typographus beetle for three years of observations and the development of Ips typographus. For Ips typographus: Flight — flight period; L1; L2; L3; — larva's growth 1, 2 and 3 stages; Mg. Egg. — Maternal galleries and egg laying; NCh — Nuptial chamber; P - pupa.

Adult parasitoids were picked in test tubes on bark of I. typographus-infested trees in autumn and spring to rear R. tutela in spruce logs in the laboratory. The collected bark was put in plastic bags and stored in a fridge at $0-1{ }^{\circ} \mathrm{C}$, and if needed taken out of the bags and kept in the laboratory at room temperature for parasitoid emergence.

Several specimens of adult parasitoids collected in the forest that emerged from the spruce bark were placed in $100 \mathrm{ml}$ Erlenmeyer flasks with damp filter paper. The flasks were loosely plugged with cotton corks and kept at $8^{\circ} \mathrm{C}$ and $15^{\circ} \mathrm{C}$ with a light regime of 16 hours. The parasitoids were fed every other day by filter paper saturation with water and honey solution $(1.5: 1)$ drops. The parasitoids that had been kept for feeding at $8{ }^{\circ} \mathrm{C}$ were exposed to room temperature for 30-40 minutes. Dead parasitoid specimens were counted daily and preserved in $70 \%$ ethanol.

In the laboratory, R.tutela were reared in I.typographus-infested spruce logs. For this purpose, $20-27 \mathrm{~cm}$ long and $9.5-12 \mathrm{~cm}$ diameter logs with cross sections coated in paraffine wax were infested with I.typographus. The spruce logs were placed in a separate room. During the experiment, the logs were dampened with water daily. When larvae of I. typographus reached the second or third instar stages, $R$. tutela males and females were released to them. The emerged parasitoids were collected in Erlenmeyer flasks and stored at $8^{\circ} \mathrm{C}$ to be used in the next experiment.
Female fertility was identified through $R$. tutela female dissections and mature egg count. Simultaneously, female and male size and female maximum gaster width were measured. To observe the developmental stages of parasitoid larvae, they were placed in glass test tubes filled with a layer of sawdust $1 \mathrm{~cm}$ thick, moistened with water. The tubes were plugged with paper corks and kept in darkness at $25^{\circ} \mathrm{C}$.

An MBS-10 binocular microscope was used to study the collected specimens. We used MS EXCEL 2010 statistical analysis package (regression) to find out if there is any link between $R$. tutela abdomen width and its fertility.

\section{Results and discussion}

In spruce forests of Moscow Region, R.tutela is found on trees infested with I.typographus and the sixtoothed spruce bark beetle Pityogenes chalcographus (L.). In such trees, we observed the presence of R. tutela only in the area of I.typographus, despite the fact that habitats of these two species of bark beetles are adjacent and their galleries cross. In trees declining due to damage by I. typographus and also infested with other bark beetles, R. tutela also parasitized larvae of the lesser spruce shoot beetle Hylurgops palliatus (Gyllenhal). 


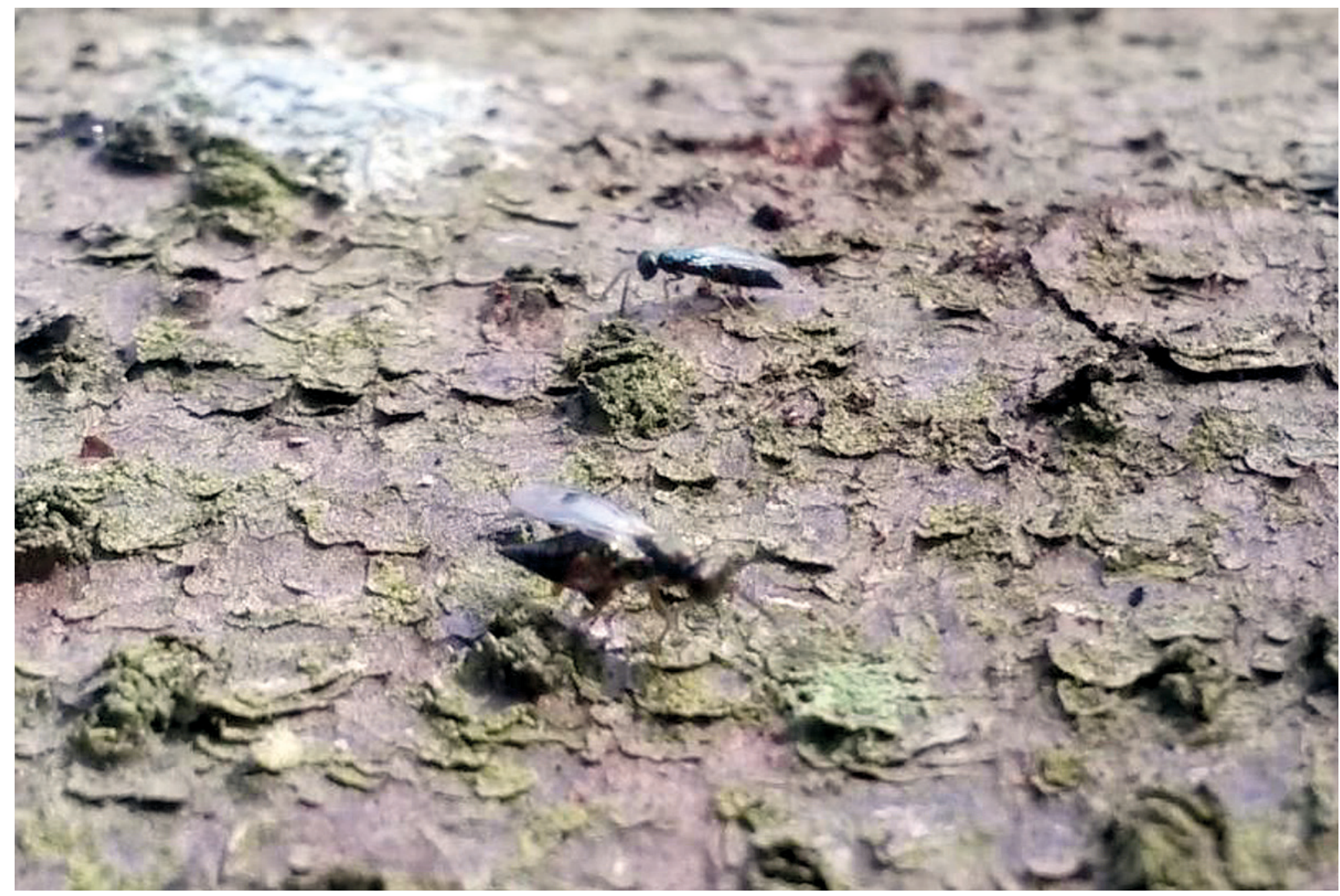

Fig. 2. Females of Rhopalicus tutela on the bark, below - the position of the female during egg laying.

According to our observations, adult $R$. tutela start to emerge in late May and fly until mid-August; in warm weather, the species can be found as late as mid-September. Its massive flight begins in June, when I. typographus develops larvae of the second and third instars (Fig. 1).

Swarming of R.tutela occurs in sites with host infestations on thin bark. The mean bark thickness is $1.39 \pm 0.1 \mathrm{~mm}$ (minimal $-0.5 \mathrm{~mm}$, maximal $-2.1 \mathrm{~mm}$ ) (Krüger and Mills, 1990). Before mating the male mounts the female for about 3 minutes. Mating lasts 1-1.5 minutes. R.tutela males are rather aggressive in keeping competing males off the females. After mating the R.tutela female seeks bark beetle larvae by moving quickly in the chosen area and spinning, knocking gently with her antennae on the bark. Once a host larva is found, the female penetrates into the bark with her ovipositor and lays an egg on the larva (Fig. 2). The mean ovipositor length is $2.2 \pm 0.2 \mathrm{~mm}$ (Krüger and Mills, 1990). R.tutela is able to lay several eggs on one host larva (Krüger and Mills, 1990; Hedqvist, 1963). The most active emergence was observed from 12:00 to 14:00 in warm sunny weather. In nature, after wintering, we observed a different ratio of males and females. During flight in different years this ratio was equal from 1 क : 3 \& to 3 क : 1 \% After mating the female paralyzes the host larva and lays an egg on or near it. R. tutela prefers to parasitize second and third instar larvae of I. typographus and sometimes also its pupae. The parasitoid larva consumes the bark beetle larva completely (Fig. 3). Older parasitoid larvae

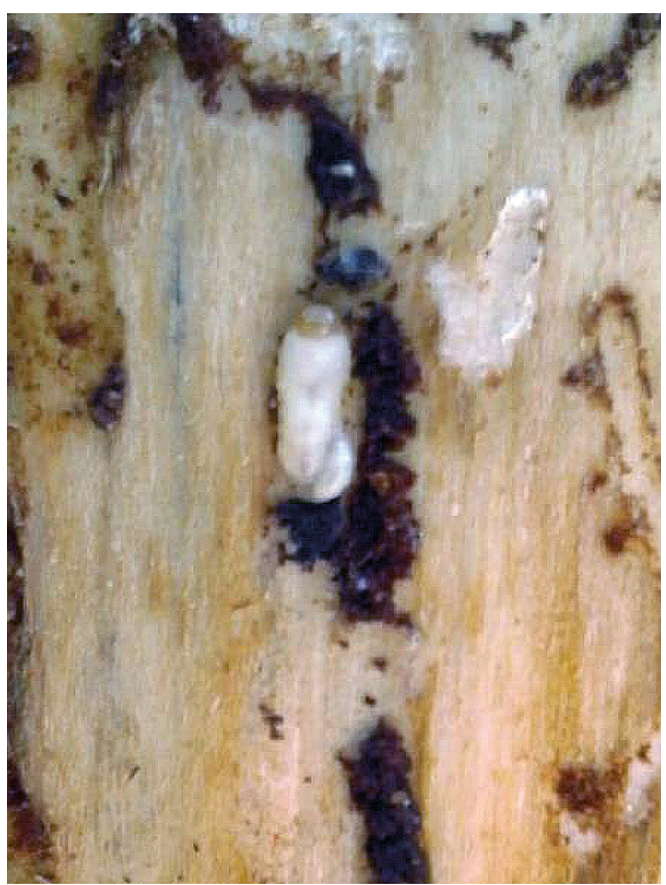

Fig. 3. Larva parasitizing on the larva of the spruce bark beetle (June 4,2013$)$. 


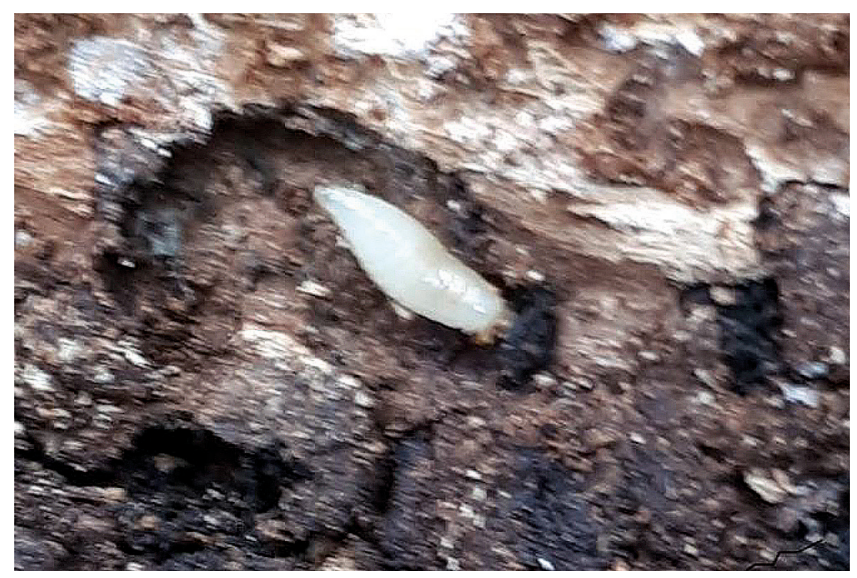

Fig. 4. Larva of Rhopalicus tutela before pupation.
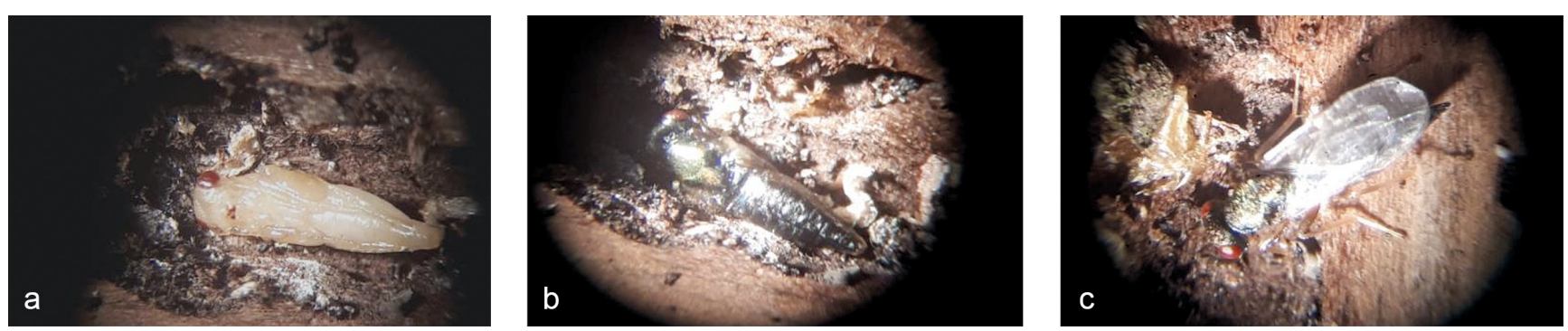

Fig. 5. Pupa Rhopalicus tutela: a - on the sixth day after pupation, b - on day 13 - before hatching imago (pupa size $2.05 \mathrm{~mm}$ ), c - on day 15 - female imago.
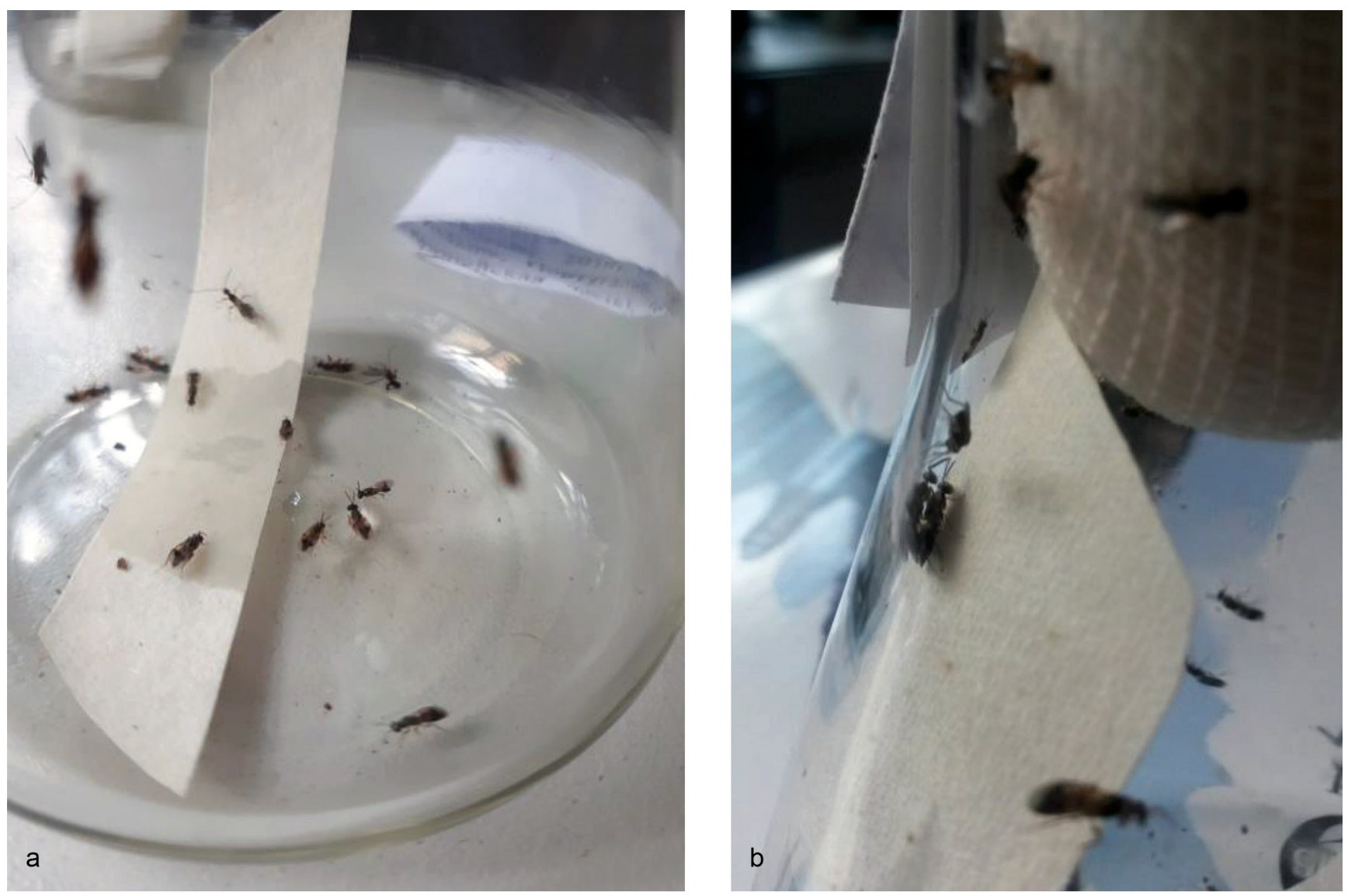

Fig. 6. The maintenance of Rhopalicus tutela in the laboratory: a — feeding with honey solution; b - mating. 


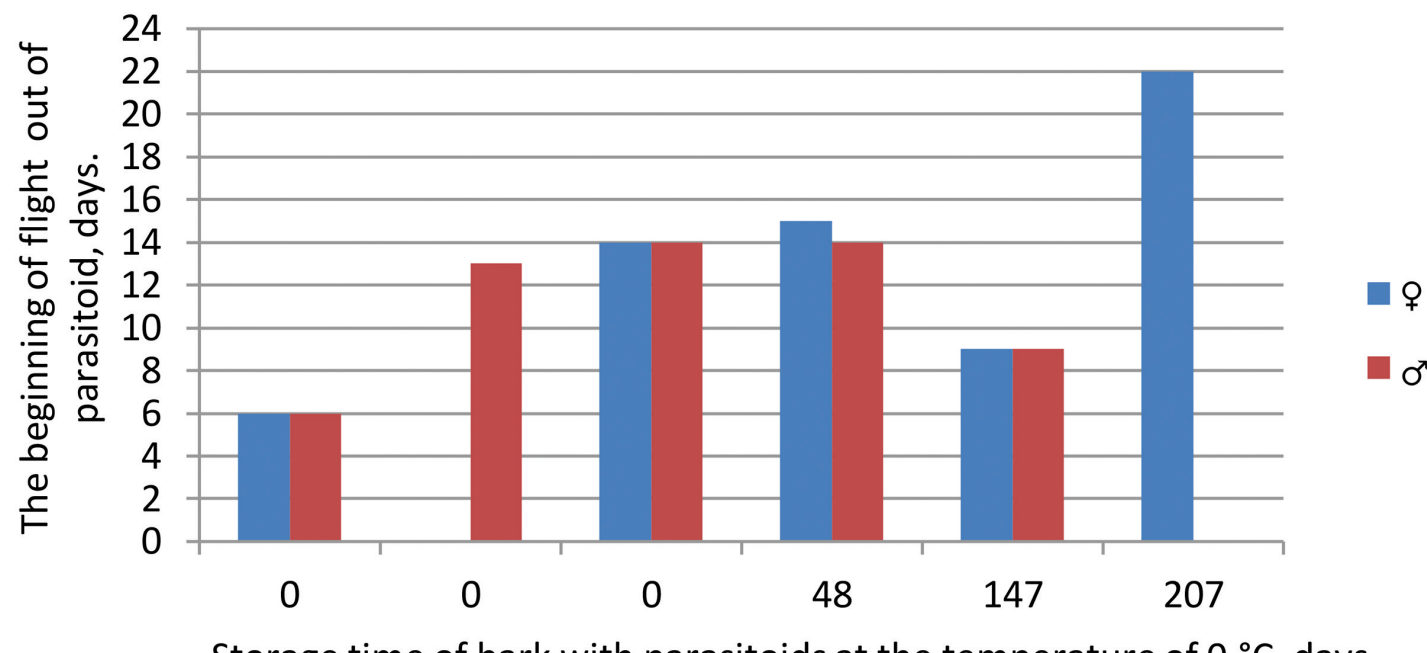

Storage time of bark with parasitoids at the temperature of $0{ }^{\circ} \mathrm{C}$, days.

Fig. 7. The beginning of the flying out of Rhopalicus tutela depending on the duration of storage of the bark at a temperature of $0^{\circ} \mathrm{C}$.

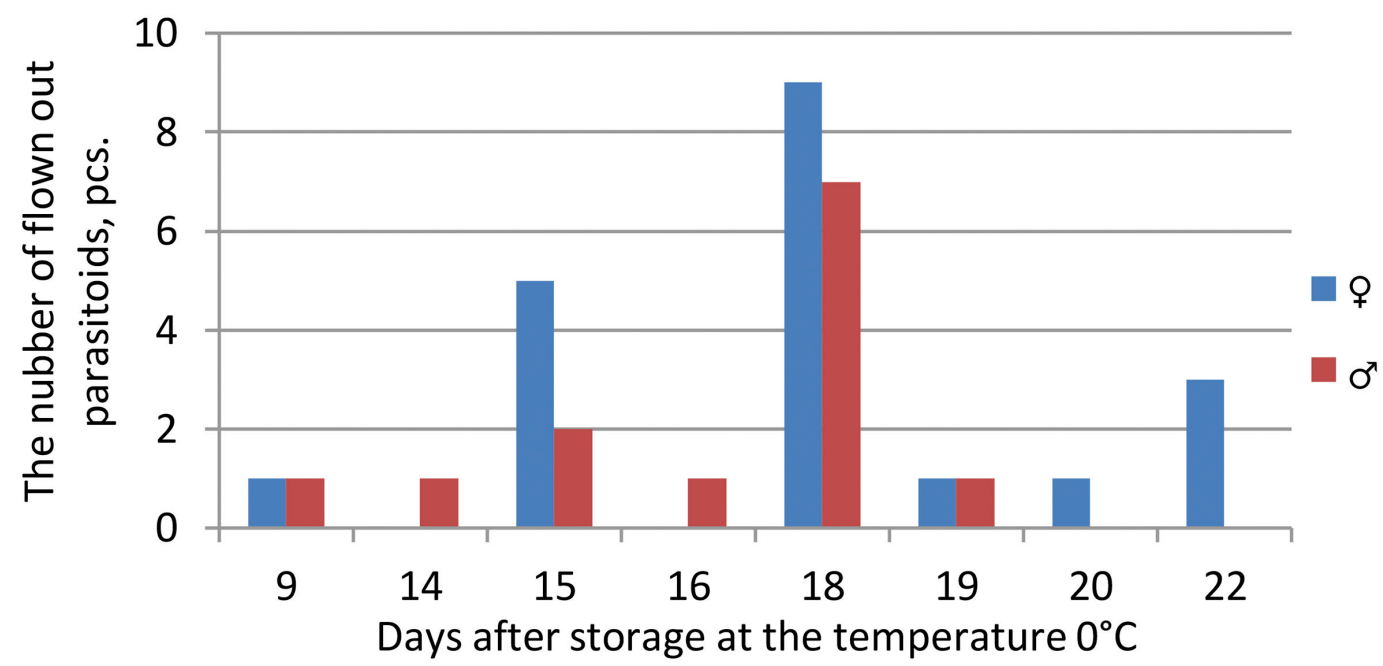

Fig. 8. The appearance of females and males of Rhopalicus tutela after storage of bark at a temperature of $0^{\circ} \mathrm{C}$.

are fusiform, slightly curved. Their bodies consist of 13 segments and a head capsule (Fig. 4). Often it positions itself in the I.typographus pupal cradle. During collection adult larvae easily drop out of the bark. The pupae of the parasitoids are formed without a cocoon; at first they are white, then gradually become dark as they develop (Fig. 5).

The last instar larvae overwinter and then pupate in spring. Imagines hatch from pupae and then chew their way out through the bark to emerge. The species has two generations per year. Development of a third generation of R. tutela is possible in warm autumn in open sunny places. We observed its emergence in mid-September.

In the laboratory, adult $R$. tutela readily feed on water and honey solution. Males are active and mate with females, aggressively competing with each other for them (Fig. 6). Rearing on spruce logs produced three generations of R. tutela.

Parasitoids fly out after 9-22 days from spruce bark collected in the fall, after 6-14 days from the bark collected at the end of April and in early May. Usually males and females emerge simultaneously but sometimes males emerge a day earlier. A duration of $0^{\circ} \mathrm{C}$ temperature exposure has no impact on the diapause period of R. tutela larvae (Fig. 7). Mean R. tutela emergence time after lab storage of bark at $0^{\circ} \mathrm{C}$ temperature was $16.6 \pm 4.1$ days. The maximal number of parasitoids emerged on the $18^{\text {th }}$ day (Fig. 8).

On spruce logs parasitoids started to emerge 14 to 16 days after infestation with I.typographus. R. tutela adult flight lasts 5-8 days; first the bark beetle flies out, then parasitoids. The simultaneous flight of both individuals is observed in the late period of flight of the bark 


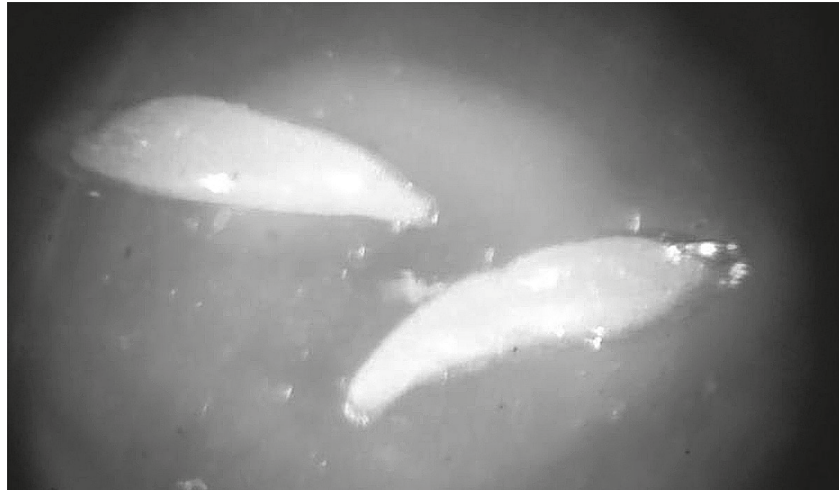

Fig. 9. Eggs of Rhopalicus tutela.

beetle and at the beginning of the flight period of $R$. tutela. The ratio of males and females flying out of the bark

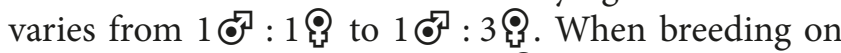
logs, the mean sex ratio is 2 fo : 1 \&.

R.tutela females at the moment of emergence immediately have mature eggs inside. Grown from spruce logs in the laboratory, $64 \%$ of females had mature eggs inside. Of those females collected in the forest during the development of the second and third stages of bark beetle larvae, $53 \%$ had mature eggs inside.

Eggs have a milky white color. Mean length is $0.67 \pm 0.11 \mathrm{~mm}$; mean width is $0.15 \pm 0.07 \mathrm{~mm}(\mathrm{n}=90)$ (Fig. 9). A female can keep up to 10 eggs and on average 3 eggs. The mean number of eggs in the females collect-

Table 1. Rhopalicus tutela fertility

\begin{tabular}{l|c|c|c}
\hline \multirow{2}{*}{$\begin{array}{c}\text { Origin of females } \\
\text { (where grown/ } \\
\text { collected) }\end{array}$} & $\begin{array}{c}\text { Number of } \\
\text { females, } \\
\text { pcs. }\end{array}$ & \multicolumn{2}{|c}{ Number of eggs, pcs. } \\
\cline { 3 - 4 } & 30 & $3 \pm 1.3$ & $1-5$ \\
\hline $\begin{array}{l}\text { Females collected in } \\
\text { the forest }\end{array}$ & 25 & $2.8 \pm 2.1$ & $1-10$ \\
\hline $\begin{array}{l}\text { Females reared in } \\
\text { the lab }\end{array}$ & $25 *$ & Min-max \\
\hline
\end{tabular}

* SD - standard deviation

Table 2. Rhopalicus tutela male and female body length

\begin{tabular}{l|c|c|c|c|c|c}
\hline \multirow{2}{*}{$\begin{array}{c}\text { Origin of females } \\
\text { (where grown/collected) }\end{array}$} & \multicolumn{2}{|c|}{ Female body length, mm } & \multicolumn{3}{c}{ Male body length, mm } \\
\cline { 2 - 7 } & $\begin{array}{c}\text { Number of } \\
\text { females, pcs. }\end{array}$ & $\begin{array}{c}\text { Mean } \\
\text { length } \pm \text { SD }\end{array}$ & Min-max & $\begin{array}{c}\text { Number of } \\
\text { males, pcs. }\end{array}$ & $\begin{array}{c}\text { Mean } \\
\text { length } \pm \text { SD }\end{array}$ & $\begin{array}{c}\text { Range } \\
\text { Forest collected specimens }\end{array}$ \\
\hline 30 & $4.35 \pm 0.58$ & $2.95-5.75$ & 46 & $3.84 \pm 0.78$ & $1.75-4.95$ \\
\hline Lab reared specimens & 25 & $3.98 \pm 0.70$ & $2.75-5.10$ & 32 & $2.63 \pm 0.27$ & $2.10-3.20$ \\
\hline All specimens & 55 & $4.18 \pm 0.66$ & $2.75-5.75$ & 78 & $3.34 \pm 0.86$ & $1.75-4.95$ \\
\hline
\end{tabular}

Table 3. Lifetime of Rhopalicus tutela at various temperatures

\begin{tabular}{|c|c|c|c|c|c|c|}
\hline \multirow{2}{*}{ Temperature } & \multirow{2}{*}{$\begin{array}{l}\text { Number of males } \\
\text { in experiment, } \\
\text { pcs. }\end{array}$} & \multicolumn{2}{|c|}{ Male lifetime, days } & \multirow{2}{*}{$\begin{array}{c}\text { Number of } \\
\text { females in } \\
\text { experiment, pcs. }\end{array}$} & \multicolumn{2}{|c|}{ Female lifetime, days } \\
\hline & & mean $\pm S D$ & $\min -\max$ & & mean $\pm S D$ & $\min -\max$ \\
\hline $8^{\circ} \mathrm{C}$ & 55 & $58 \pm 44$ & $2-153$ & 76 & $36 \pm 45$ & $3-153$ \\
\hline $15^{\circ} \mathrm{C}$ & 6 & $9 \pm 2$ & $7-10$ & & & \\
\hline
\end{tabular}

ed in the forest and reared in the laboratory was similar (Table 1).

The sizes of males and females of $R$. tutela are summarized in Table 2.

The relationship between abdomen width and fertility was poor for females collected in the forest (Fig. 10). The statistical correlation coefficient and model parameters are not significant $(r=0.18$; Student's $t$-test is $0.875<\mathrm{t}$ crit.). The relationship between the width of as well ( $r=0.29-$ it is slightly higher but statistically insignificant, Student t-test criterion equals 1.45). Nevertheless, it indicates that fertility rises as abdomen width grows. A similarly poor link was found in studies of R. tutela body size and its fertility interaction.

Rhopalicus tutela lifetime at $8^{\circ} \mathrm{C}$ is higher than at $15^{\circ} \mathrm{C}$ (Table 3). Males live longer than females. We took some females from this experiment for rearing, thus their lifetime was not defined accurately. Nevertheless females lived over 26 days at $8^{\circ} \mathrm{C}$ and over 10 days at $15^{\circ} \mathrm{C}$. Parasitoids that emerged from the last experiment $\operatorname{logs}$ lived at $8^{\circ} \mathrm{C}$ from September until February. The average female lifetime at $8^{\circ} \mathrm{C}$ is 36 days, while the maximum is 153 days.

The development of $R$. tutela is highly dependent on temperature, as indicated by many studies. $R$. tutela development duration according to many studies is shown in Table 4.

An increase in temperature shortens development periods, as development can proceed without diapause. As a result of our experiments in the lab at $22-24^{\circ} \mathrm{C}$, 14-16 days elapse from settlement to the start of emergence out of the bark of parasitoids.

We produced three generation of $R$. tutela in the lab from June to early September on spruce logs. A low temperature impacts development duration but does not affect the duration of diapause. Females of R. tutela do not need a preoviposition feeding period to lay eggs. However, the abdomen of lab-reared females and fertility is poor 


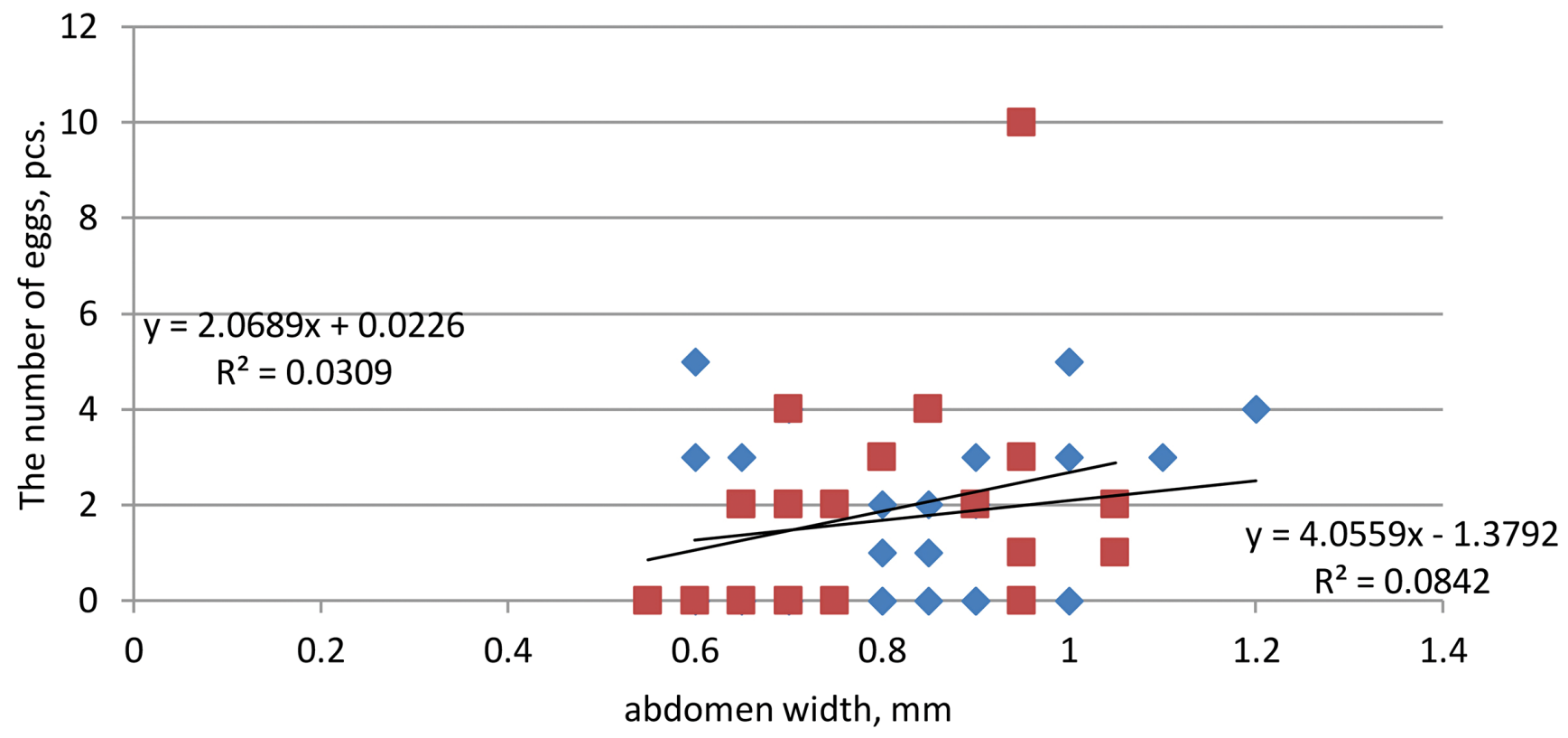

Females collected in the forest $\quad$ Females grown in the laboratory

Fig. 10. Dependence of the fertility of females Rhopalicus tutela on the width of the abdomen.

Table 4. Rhopalicus tutela duration of development in lab from eggs to adults at different temperatures

\begin{tabular}{c|c|c|c|l}
\hline \multirow{2}{*}{$\begin{array}{c}\text { Temperature, } \\
\mathrm{C}^{\circ}\end{array}$} & \multicolumn{3}{|c|}{ Duration development, days } & \multirow{2}{*}{ Source } \\
\cline { 2 - 5 } & eggs & from larva to pupa & from egg to imago & \multirow{2}{*}{ Györfi, 1942} \\
\hline $14-16$ & & & $42-48$ & Krüger and Mills, 1990 \\
\hline 15 & $4.3 \pm 0.4$ & $19.3 \pm 0.5$ & $33.8 \pm 1.5$ & Györfi, 1942 \\
\hline $16-18$ & & & $30-35$ & Györfi, 1942 \\
\hline $20-22$ & & $20-27$ & Hougardy and Gregoire, 2004 \\
\hline 22 & & 20 & Krüger and Mills, 1990 \\
\hline 25 & $2.6 \pm 0.3$ & $5.8 \pm 0.7$ & $14.8 \pm 0.5$ & \\
\hline
\end{tabular}

the preoviposition period is momentous. It was found that with additional feeding $R$. tutela lifetime is prolonged and females lay more eggs; the period before oviposition lasts $3.3 \pm 1$ days and from the second to eighth day females lay a stable number of mature eggs (Hougardy and Gregoire, 2004). It is also suggested with presence of the host, egg formation is faster and larvae size affects sex ratio. Body length does not affect viability; nevertheless, larger species live longer without additional feeding (Hougardy and Gregoire, 2004). We did not find a significant relationship between body size and fertility, however, such a relationship was shown by Hougardy and Gregoire (2004).

\section{Conclusions}

Rhopalicus tutela is one of the most common spruce bark beetle parasitoids in Moscow Region. It can be considered as a prospective agent for biological protection of spruce forests in the region. The development of several generations per year, a short life cycle, fertility, and the presence of mature eggs after overwintering of $R$. tutela make it possible to rapidly increase its number through artificial breeding.

\section{References}

Bouček, Z., Půlpán, J., and Śedivý, J. 1953. Poznámky o blanokřídlých cizopasnících kưrovce smrkového (Ips typographus L.) v ČSR . Zoologické a entomologické listy 2(16):145-158.

Chilakhsaeva, E.A. 2017. Rhopalicus tutela (Hymenoptera: Pteromalidae) is a promising entomophage for use in the biological protection system of spruce from the bark beetle typographer. All-Russian Research Institute of Forestry and Mechanization of Forestry 49:143-147. (In Russian)

Eck, R. 1990. Bionomic notes on some parasitic Hymenoptera associated with bark beetles, especially with Ips typographus (Insecta: Hymenoptera; Braconidae, Chalcidoidea). Faunistiche Abhandlungen 17(2):115-126. 
Girits, A. A. 1975. Fundamentals of the biological control of the bark beetle typograph (Ips typographus L., Coleoptera, Ipidae). 154 pp. Lviv: Publishing house Vishka School. (In Russian)

Györfi, J. 1942. Fürkeszdarazs kutatasaim eredmenye, különöstekintettel a mellekgazda kerdesre. Erdeszeti Kiserletek 44:1-165.

Hedqvist, K.J. 1963. Die Feinde der Borkenkafer in Schweden, I. Erzwespen (Chalcidoidea). Studia Forestalia Suecica 11:71-79.

Hougardy, E. and Gregoire J.-C. 2003. Cleptoparasitism increases host finding abilities in the polyphagous parasitoid species Rhopalicus tutela (Hymenoptera: Pteromalidae). Behavioural Ecology and Sociobiology 55:184-89. https://doi.org/10.1007/s00265-003-0688-y

Hougardy, E. and Gregoire, J.-C. 2004. Biological differences reflect host preference in two parasitoids attacking the bark beetle Ips typographus (Coleoptera: Scolytidae) in Belgium. Bulletin of Entomological Research 94(4):341347. https://doi.org/10.1079/BER2004305
Kharitonova, N. Z. 1972. Entomophages of coniferous bark beetles. 178 pp. M: Forest industry. (In Russian)

Kolomiets, N. G. and Bogdanova, D. A. 1980. Parasites and predators of xylophagues in Siberia. 278 pp. Novosibirsk: Nauka. (In Russian)

Krüger, K. and Mills, N.J. 1990. Observations on the biology of three parasitoids of the spruce bark beetle, Ips typographus (Col., Scolytidae), Coeloides bostrichorum, Dendrosoter middendorffii (Hym., Braconidae) and Rhopalicus tutela (Hym., Pteromalidae). Journal of Applied Entomology 110:281-291. https://doi.org/10.1111/j.1439-0418.1990. tb00124.x

Noyes, J.S. 2019. Universal Chalcidoidea Database. World Wide Web electronic publication. https://www.nhm. ac.uk/our-science/data/chalcidoids/database/

Tselikh, E. V. 2012. Hymenoptera, Pteromalidae; pp. 150161 in: Annotated catalogue of the insects of Russian Far East. Volume I. Hymenoptera, edited by Lelej, A. S. Vladivostok: Dalnauka. (In Russian) 